\title{
Responses of enteric bacteria to environmental stresses in seawater
}

\author{
Marc TROUSSELLIER a , Jean-Luc BONNEFONT ${ }^{\text {b }}$, Claude COURTIES ${ }^{\text {a }}$, Annick DERRIEN ${ }^{c}$, \\ Elizabeth DUPRAY ${ }^{c}$, Michel GAUTHIER ${ }^{d}$, Michèle GOURMELON ${ }^{c}$, Fabien JOUX ${ }^{e}$, \\ Philippe LEBARON ${ }^{e}$, Yvan MARTIN ${ }^{b}$, Monique POMMEPUY ${ }^{c}$ \\ ${ }^{a}$ Laboratoire d'hydrobiologie marine-UMR CNRS 5556, université Montpellier-II, 34095 Montpellier cedex 05, France \\ ${ }^{b}$ Institut océanographique Paul-Ricard, Ile des Embiez, 83140 Six-Fours-Les-Plages, France \\ ' Ifremer - DEL, laboratoire de microbiologie, BP 70, 29280 Plouzané, France \\ ${ }^{d}$ Unité INSERM 452, UFR de médecine, avenue de Valombrose, 06107 Nice cedex 02, France \\ ${ }^{e}$ Laboratoire Arago, UMR CNRS 7621, Institut national des sciences de l'univers, université Pierre-et-Marie-Curie, \\ 66651 Banyuls-sur-Mer cedex, France
}

(Revised 22 April 1998, accepted 27 April 1998)

\begin{abstract}
The effects of different environmental facturs (nutrient deprivation, hyperosmotic shock, exposure to light) on enteric bacteria which have been transferred into the marine environment, have been studied experimentally (microcosms) by considering demographic, physiological and genetic responses in Escherichia coli or Sulmonella typhimurium populations. Short-term experiments $(\leq 48 \mathrm{~h})$ showed that nutrient deprivation induced limited changes in measured bacteriological variables, but when combined with hyperosmotic shock, it results in an energy charge decrease and inactivation of membrane transport. Light exposure mainly affects the colony-forming capacity of bacterial populations. Combining different stress factors confirmed the rapid appearance of a viable, but nonculturable state (VBNC) in populations of E. coli and S. typhimurium. It has been shown that cellular forms other than those previously described in the literature can be generated following incubation in seawater. It was also established that pre-adaptation phenomena may occur, leading to better survival (e.g. pre-incubation in seawater in darkness enhanced survival under light exposure). An explanation concerning these phenomena can be found by looking at the rpoS gene which controls the expression of numcrous genes and can trigger a general anti-stress response under different adverse conditions. Although the results provide better comprehension of the fate of enteric bacteria in the marine environment, they also raise numerous questions related to fundamental and applied problems, given in the conclusion of this paper. (. Elsevier, Paris
\end{abstract}

enteric bacteria / seawater / physiology / cellular states / genetics

Résumé - Réponses des bactéries d'origine entérique aux stress environnementaux en milieu marin. Les effets de différents facteurs environnementaux (carence nutritive, choc hyperosmotique, exposition à la lumière) auxquels sont confrontées les bactéries entériques rejetées dans le milieu marin ont été étudiés expérimentalement (microcosmes) en considérant les réponses démographiques, physiologiques et génétiques des populations d'Escherichia coli ou de Salmonella typhimurium. À court terme ( $\leq 48 \mathrm{~h}$ ), la seule carence nutritive induit des modifications limitées des variables mesurées alors que, combinée au choc hyperosmotique, elle aboutit notamment à une diminution de la charge énergétique et à l'inactivation des transports membranaires. L'exposition à la lumière contribue surtout à une très forte inhibition de la capacité à former des colonies des populations bactériennes. La combinaison des différents stress a confirmé l'apparition rapide d'un état viable non cultivable dans les populations bactériennes de E. coli et $S$. typhimurium. Il a été montré que des états cellulaires, autres que ceux précédemment décrits dans la littérature. peuvent être engendrés au cours de l'incubation dans l'eau de mer. 11 s'est avéré également que des phénomènes de préadaptation peuvent se produire et conduire à une amélioration de la survie (e.g., une incubation préalable dans de l'eau de mer à l'obscurité améliore la survie à une exposition à la lumière). Ces phénomènes trouvent leur origine dans l'expression du gène rpoS qui régule celle de nombreux autres 
gènes permettant de déclencher une réponse antistress générale pour différents types d'inducteurs. Si les résultats obtenus permettent de mieux comprendre le devenir des entérobactéries dans le milieu marin, ils posent aussi de nombreuses questions qui peuvent déboucher sur différentes problématiques finalisées et fondamentales qui sont évoquées dans la conclusion de cet article. (C) Elsevier, Paris

entérobactéries / eau de mer/ physiologie / états cellulaires / génétique

\section{INTRODUCTION}

When enteric bacteria reach coastal marine environments, their fate depends on various processes, leading either to their disappearance or to an alteration in their physiological state (figure 1). Compared with the digestive tract environment, the marine environment features lower temperatures (the optimum growth temperature of faecal coliforms being $37^{\circ} \mathrm{C}$ ), higher salinity (38 in the Mediterranean), the presence of solar radiation in surface waters (UV-A, -B, visible light; penetration being dependent on turbidity of the water), an often-elevated oxygen concentration, a low amount of organic matter (about $100 \mu \mathrm{g} \mathrm{L}^{-1}$ or less of labile dissolved organic matter), an autochthonous bacterial community known to be more competitive than allochthonous bacteria, with respect to uptake of the few nutrients available, and lastly, the presence of other planktonic organisms (especially nano-

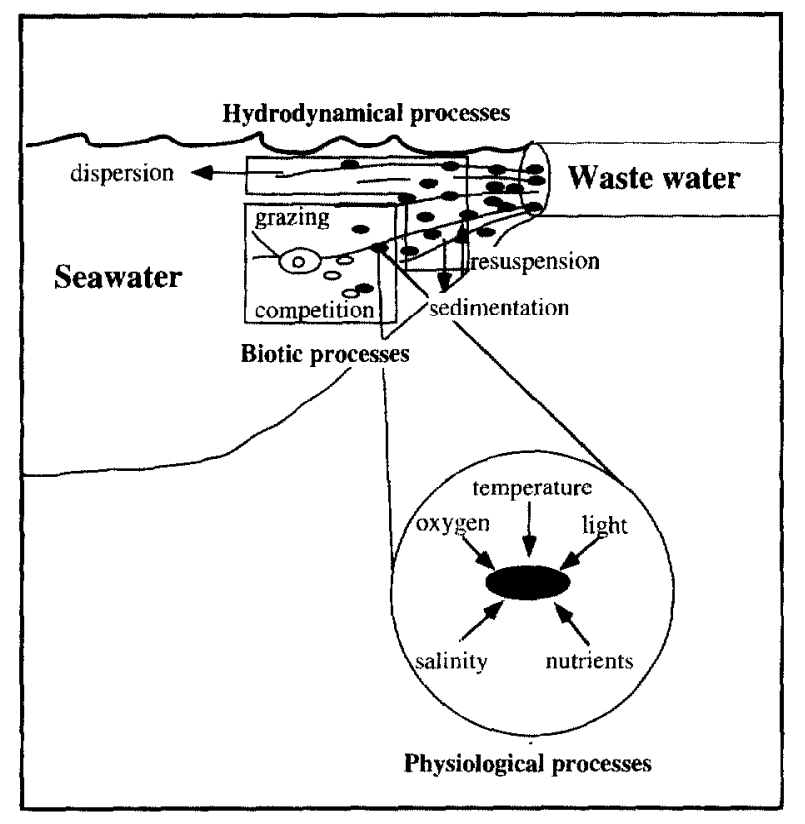

Figure 1. Main environmental factors involved in processes which affect the fate of enteric bacteria discharged into the sea. plankton), which are potential predators for bacterial cells.

Enteric bacteria are therefore confronted with a new environment which can generate different types of stress. A detailed account of known responses of bacterial cells to different types of stress is not possible here, but some basic information should be mentioned.

It has been twelve years since Brayton et al. [5] asked the following question, with respect to allochthonous bacteria entering marine coastal waters: "is there then, a rapid "die-off" during unfavourable conditions... or rather do the organisms employ a survival strategy until more satisfactory conditions for growth occur ?". At the end of the paper, they give the following answer regarding different bacterial species of sanitary importance: "Clearly, a nonculturable but viable and dormant stage exists for those bacteria examined to date".

The "viable but nonculturable" (VBNC) cellular state corresponds to a cell which is unable to divide in or on a nutritional medium, which normally supports the growth of that cell, in spite of the fact that it shows real or potential metabolic activity [36]. Metabolic activity of nonculturable cells may be detected at the cellular level, either by the capacity of the cells to respond (metabolic synthesis) to an addition of nutrients (the "direct viable count method, [27]) or by maintaining or inducing respiratory activity [47], enzyme activity [38], or membrane poten. tial $[21,32]$.

Since the early 1980s, the VBNC state has been demonstrated for more than twenty species of bacteria [36], including autochthonous marine species. This state is of special concern when considering its potential consequences in terms of public health because, by definition, VBNC cells of bacterial pathogenic strains escape detection by conventional means (cultural medium), and could become a source of infection if they had a means of retaining or regaining their pathogenicity [40]. Recently, new methods have been proposed to detect viable but nonculturable pathogenic bacteria in water [39]. 
However, in spite of considerable methodological and conceptual advances, our knowledge concerning the behaviour of enteric bacteria in the marine environment is still very fragmentary. Until the beginning of the $1990 \mathrm{~s}$, most studies were either focused on research concerning cellular and molecular mechanisms, considering the effects of only one environmental factor at a time (e.g. osmotic stress; [7]), or describing the effects of different factors, but using a "single level of observation" of the cellular fate (e.g. culturable cells, [37]).

The overall objective of our joint study, initiated and supported by the Programme national d'océanographie côtière (PNOC), was to specify the demographic, physiological and genetic characteristics of populations of enteric bacteria subjected to different stress factors of the marine environment. Taking into account published studies, we have identified three major stress factors which occur in the marine environment: lack of organic matter [25], salinity [14], and sunlight [3], particularly in relation to its photochemical effects [8].

\section{MATERIALS AND METHODS}

\subsection{Bacterial strains and growth conditions}

For most of the experiments concerning the fate of enteric bacteria in the marine environment, strains of two different bacterial species were used: Escherichia coli (K-12 MC 4100; [6]) and Salmonella typhimurium. (ref. 60.62T, Collection Institut Pasteur, Paris). Different E. coli mutants and their parental strains were both used to study the genetic background of responses to different environmental factors. These strains will be identified in the legends of figures illustrating the results of experiments in which they were used.

The strains were generally grown in nutrient rich media, at $37^{\circ} \mathrm{C}$. They were collected and washed by centrifugation during the exponential phase. Some experiments were also carried out with strains in the stationary phase.

\subsection{Experimental conditions simulating the effects of stress factors}

Three major environmental stresses were tested in a series of different experiments:
- nutrient deprivation: incubation in artificial seawater or physiological water without (OM-) or with organic substrate addition (glucose $\left.100 \mathrm{mg} \mathrm{L}^{-1}\right)(\mathrm{OM}+$ ),

- saline stress: incubation in artificial seawater (Instant Ocean, Aquarium Systems, Sarrebourg, France or Sea Salt, Sigma, St Louis, MO; salinity: 35-38) (S+) or physiological water $\left(\mathrm{NaCl} 9 \mathrm{~g} \mathrm{~L}^{-1}\right)(\mathrm{S}-)$,

- light: exposure to natural sunlight, or visible artificial light (Lumilux neon 32, OSRAM, New Brunswick incubator) $(\mathrm{L}+)$ or incubation in darkness $\left(\mathrm{L}_{-}\right)$.

Most of the experiments were temperature-controlled $\left(20^{\circ} \mathrm{C}\right)$. The different stress factors were tested either individually, or in combination following the experimental design shown in table $I$.

Table I. Illustration of experimental designs used to generate one or several stress factors.

\begin{tabular}{cccc}
\hline \multicolumn{3}{c}{ Environmental factors } & \\
\cline { 1 - 3 } $\begin{array}{c}\text { Organic } \\
\text { matter" } \\
(\mathbf{O M})\end{array}$ & $\begin{array}{c}\text { Salinity } \\
\text { (S) }^{\mathbf{b}}\end{array}$ & $\begin{array}{c}\text { Light }^{\mathrm{c}} \\
(\mathbf{L})\end{array}$ & $\begin{array}{c}\text { stress } \\
\text { number }\end{array}$ \\
\cline { 1 - 3 }+ & - & - & 0 \\
- & - & - & $1(\mathrm{OM}-)$ \\
+ & + & - & $1(\mathrm{~S}+)$ \\
+ & - & + & $1(\mathrm{~L}+)$ \\
- & + & - & $2(\mathrm{OM}-, \mathrm{S}+)$ \\
- & - & + & $2(\mathrm{OM}-, \mathrm{L}+)$ \\
+ & + & + & $2(\mathrm{~S}+, \mathrm{L}+)$ \\
- & + & + & $3(\mathrm{OM}-, \mathrm{S}+, \mathrm{L}+)$ \\
\hline
\end{tabular}

$a_{+/-}:$presencc/absence of assimilable organic matter.

$\mathrm{b}_{++-}$: natural or artificial seawater/physiological water.

$\mathrm{C}_{+/-}$: solar or visible light/dark.

Osmoregulation experiments were carried out in microcosms using $0.22 \mu \mathrm{m}$ filtered natural water from Morlaix estuary, France. The salinity was adjusted to 35 . Glycinebetaine and proline $(1 \mathrm{mM})$ were added in some microcosms.

Acid resistance was tested by numbering bacteria after

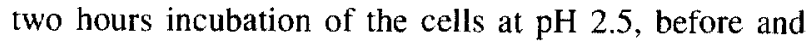
after a $100 \mathrm{~min}$ incubation period in distilled water or diluted or non-diluted seawater.

\subsection{Bacteriological variables}

Depending on the experiment in question, different bacteriological variables were measured. Epifluorescent microscopy was used to obtain total bacterial counts (TC) 
after staining the cells with 4,6-diamidino-2-phenylindole (DAPI; Sigma; $2.5 \mu \mathrm{g} \mathrm{mL}^{-1}$ final concentration) and filtering through black polycarbonate membrane filter's (0.2 $\mu \mathrm{m}$ pore-size, Nuclepore).

The culturable cells were counted as colony forming units (CFU) by plating a fraction of the sample on nutritive agars with the same composition as the medium on which the strains were grown on (e.g. LB agar (Difco) if the strain was grown in LB medium (Difco)) and at a temperature identical to that at which they were cultured.

Direct viable count (DVC) was estimated using the technique described by Kogure et al. [27] via epifluorescence microscopy or flow cytometry $[30,44]$. Bacterial cells displaying respiratory activity were obtained using the technique described by Rodriguez et al. [42]. Cells with a damaged or intact cytoplasmic membrane were enumerated using the Live/Dead ${ }^{(B)}$ BacLight $^{\mathrm{TM}}$ kit (Molecular Probes Europe, The Netherlands). The relative quantity of cellular DNA was estimated by staining the cells with Hoechst 33342 (Sigma) and measuring cellular fluorescence by flow cytometry [29].

Adenylate energy charge [2] was computed from the determination of adenine nucleotides (AMP, ADP, ATP). The amount of ATP was assessed following the HolmHansen and Booth method [19], as modified by Laborde [28], using an ATP photometer (LKB 1250 luminometer, LKB Instruments, Finland). AMP and ADP were estimated after enzymatic phosphorylation to ATP.

Incorporation of ${ }^{14} \mathrm{C}$-glucose was estimated by the Wright and Hobbie [45] method using a final concentration of labeled substrate of $5 \mu \mathrm{g} \mathrm{C} \mathrm{L}^{-1}$.

The effects of hyperosmotic shock on transmembrane transport of substrates by $E$. coli cells were investigated with ${ }^{14} \mathrm{C}$-labelled carbohydrates or amino acids taken up through either group translocation (methyl- $\alpha$-D-glucopyranoside $=\alpha$-MG), proton symport ( $\beta$-D-methylthiogalactopyranoside $=$ TGP), sodium co-transport (proline,TGP) or protein-binding systcm (histidine, maltose). Bacterial cells were submitted to osmotic shock in salted ( $\mathrm{NaCl} 0.5 \mathrm{M}$ ) buffered medium (M9 medium, [33]) or in natural seawater prior to transport measurements [14].

Intracellular osmoprotectants were characterised through ${ }^{1} \mathrm{H}$-nuclear magnetic resonance according to the following protocol [9]: after six days of incubation in microcosms, Salmonella cells were filtered through $0.22-\mu \mathrm{m}$ pore-size membrane filters and extracted twice with trichloroacetic acid and ether. The extracts were dissolved in enriched deuterium. 'H-NMR spectra were obtained using a Bruker AC300 spectrometer (Bruker Spectrospin, Wissembourg, France) at $300.13 \mathrm{Mhz}$ with a $5 \mathrm{~mm}$ dual probe.

\section{RESULTS AND DISCUSSION}

\subsection{Culturability loss and global physiological changes in Escherichia coli populations subjected to different stress conditions in seawater}

Changes in total and CFU counts of a population of $E$. coli subjected or not subjected to nutrient deprivation (OM-/OM+), hyperosmotic shock $\left(\mathrm{S}+/ \mathrm{S}_{-}\right)$and sunlight exposure $(\mathrm{L}+/ \mathrm{L}-)$, imposed separately or in combination, are illustrated in figure 2. No significant changes $(P>0.05)$ in total counts were observed within two days. Decrease rates $\left(\mathrm{h}^{-1}\right)$ of CFU counts (table II) were mini-

Table II. Slopes $\left(\mathrm{h}^{-1}\right)$ (lower, upper $95 \%$ confidence limits) from linear regression models fitted to CFU count changes (see figure 2) of a population of $E$. coli subjected or not to nutrient deprivation $(\mathrm{OM}-, \mathrm{OM}+)$, hypcrosmotic shock $(\mathrm{S}+, \mathrm{S}-)$ and sunlight exposure $(\mathrm{L}+, \mathrm{L}-)$, imposed separately or in combination. See figure 2 legend for experimental conditions. Counts were first $\log _{10}$-transformed.

\begin{tabular}{ccc}
\hline & OM+ & OM- \\
\hline $\mathrm{S}-\mathrm{L}-+0.050(+0.034,+0.066)$ & $-0.005(-0.009,-0.0001)$ \\
$\mathrm{S}+\mathrm{L}--0.006(-0.011,-0.002)$ & $-0.020(-0.028,-0.0140)$ \\
$\mathrm{S}-\mathrm{L}+-0.060(-0.087,-0.031)$ & $-0.110(-0.160,-0.0570)$ \\
$\mathrm{S}+\mathrm{L}+-0.120(-0.171,-0.059)$ & $-0.100(-0.178,-0.0280)$ \\
\hline
\end{tabular}

mum when cells were only subjected to nutrient deprivation (OM-, $\left.\mathrm{S}_{-}, \mathrm{L}_{-}\right)$and maximum when they were exposed to light, with or without a hyperosmotic shock (S-, L+ or S+, L-). Confidence intervals for the slopes showed that light induced a significantly higher CFU loss rate than hyperosmotic shock (table $I I)$.

After 40 h of light exposure in artificial seawater (OM-, $\mathrm{S}+, \mathrm{L}+$ ), only viable but nonculturable (VBNC) state was detected (significant DVC value but no detectable CFU) while, in the dark (OM-, S+, L-), a significant proportion of $E$. coli cells remained culturable (figure 3 ).

Energy charge of the cells (table III) decreased for all types of studied stresses. Nutrient deprivation alone (OM-, S-, L-) resulted in the lowest energy charge decrease, while hyperosmotic shock and light exposure applied separately or in combination induced a similar 


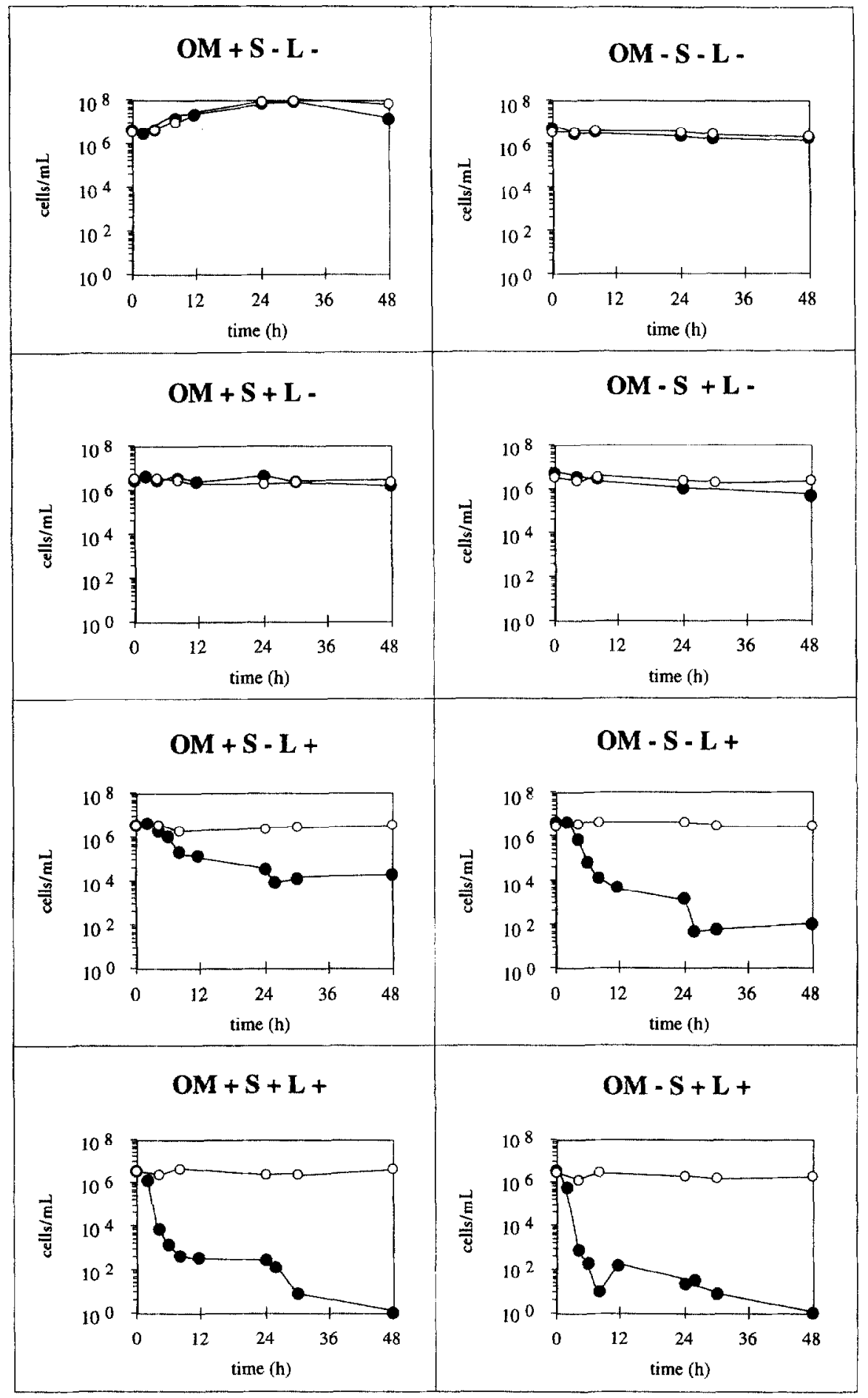

Figure 2. Changes in total $(O)$ and $\mathrm{CFU}(\odot)$ counts in an E. coli population, under different experimental conditions simulating different environmental factors (cf. figure 1 with $\mathrm{OM}_{+}=+$glucose $100 \mathrm{mg} \mathrm{L}^{-1}, \mathrm{OM}_{-}=$no substrate addition; $\mathrm{S}+=37, \mathrm{~S}-=9 ; \mathrm{L}_{+}=$sunlight exposure, with a maximum measured intensity of approximately $300 \mathrm{~W} \mathrm{~m}^{-2}$ at $1 \mathrm{pm}$ (local time). $\mathrm{L}_{-}=$dark incubation). 


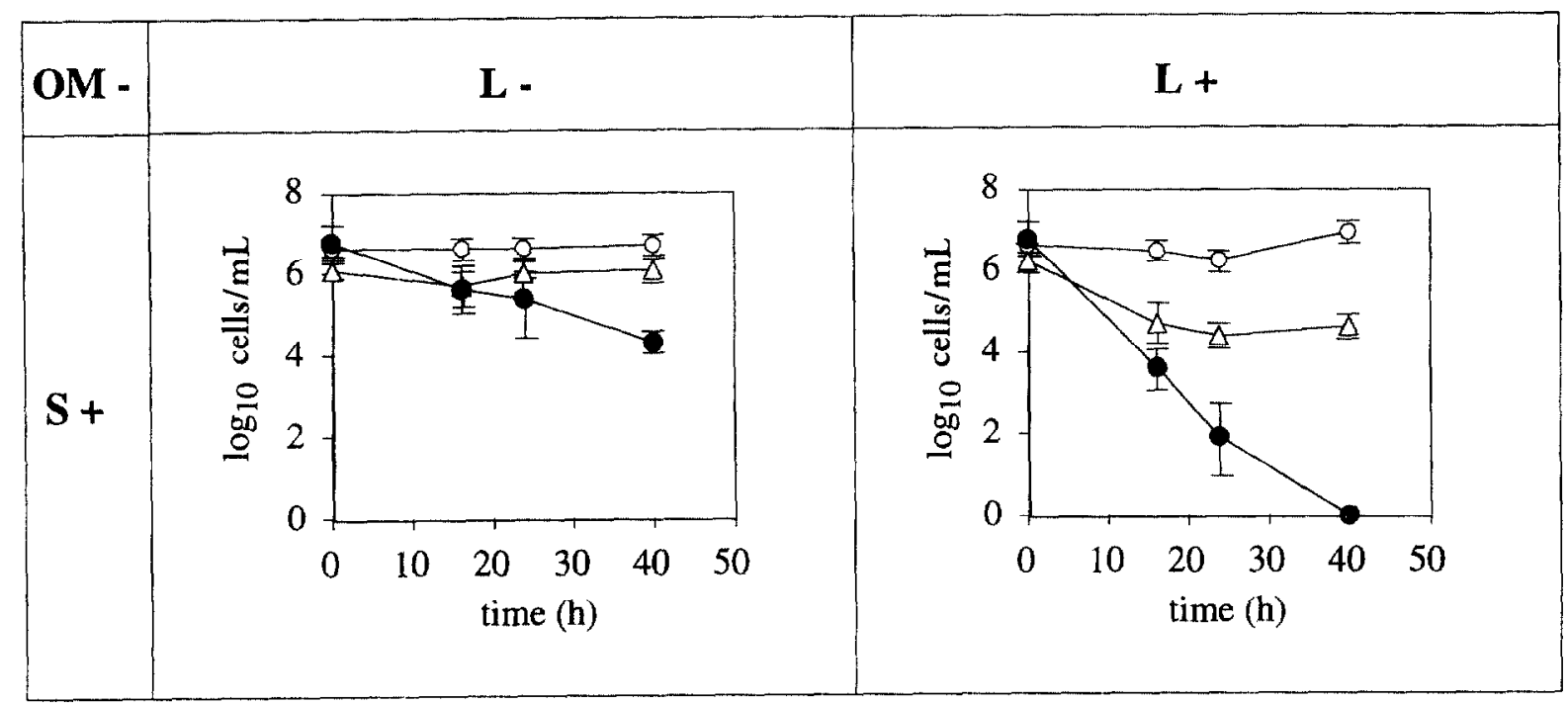

Figure 3. Changes in total $(O), \mathrm{CFU}(\bullet)$ and DVC $(\Delta)$ counts in an $E$. coli population incubated in artificial seawater $(\mathrm{OM}-$-, S+ $=34)$ and exposed or not to visible light $\left(\mathrm{L}_{-}=\right.$incubation in the dark, $\mathrm{L}+=$ continuous exposure to artificial visible light $\left.\left(125 \mathrm{~W} \mathrm{~m}^{-2}\right)\right)$. Mean of three experiments $\pm \mathrm{SD}$.

decrease. Preliminary experiments have shown that the total glucose uptake (\% of the added amount of ${ }^{14} \mathrm{C}$ glucose retained by $E$. coli cells) of cells only submitted to nutrient deprivation (OM-, S-, L-) was constant over two days $(5.33 \% \pm 0.471$, mean \pm SD) and higher than when the cells were also exposed to hyperosmotic shock with or without light exposure (OM-, S+, L-: $0.60 \% \pm$ 0.08 ; $\mathrm{OM}-, \mathrm{S}+, \mathrm{L}+: 0.50 \% \pm 0.01)$. The most detailed study concerning different molecular transport systems (figure 4) showed a large decrease in accumulation of labelled molecules when the cells were suspended in seawater.
These results allow us to consider that in the short term, the culturability and the physiological characteristics studied of $E$. coli cells were affected to different degrees depending on the type of stress:

- nutrient deprivation provided the weakest culturability loss and energy charge decrease; glucose uptake capacity and the ability to transport glucosides and amino acids were maintained.

- hyperosmotic shock resulted in cell "closure", i.e. a more rapid degradation of energy charge, and a decreased capacity to transport nutrients.

Table III. Effect of nutrient deprivation, hyperosmotic shock and light exposure on energy charge of E. coli population (mean of two experiments, standard deviation in parentheses). See figure 2 for key to experimental conditions symbols.

\begin{tabular}{|c|c|c|c|c|c|c|c|c|c|c|c|}
\hline & \multirow{2}{*}{$\begin{array}{c}\text { Experimental } \\
\text { conditions }\end{array}$} & & \multicolumn{3}{|c|}{ time (h) } & \multirow{2}{*}{\multicolumn{3}{|c|}{$\begin{array}{c}\text { Experimental } \\
\text { conditions }\end{array}$}} & \multicolumn{3}{|c|}{ time (h) } \\
\hline & & & 0 & 24 & 48 & & & & 0 & 24 & 48 \\
\hline OM+ & S- & L- & $\begin{array}{c}0.851 \\
(0.068)\end{array}$ & $\begin{array}{c}0.807 \\
(0.181)\end{array}$ & $\begin{array}{c}0.768 \\
(0.187)\end{array}$ & OM- & S- & L-- & $\begin{array}{c}0.851 \\
(0.068)\end{array}$ & $\begin{array}{c}0.543 \\
(0.075)\end{array}$ & $\begin{array}{c}0.634 \\
(0.151)\end{array}$ \\
\hline$"$ & $\mathrm{~S}+$ & $\mathbf{L}_{-}$ & " & $\begin{array}{c}0.513 \\
(0.131)\end{array}$ & $\begin{array}{c}0.561 \\
(0.170)\end{array}$ & $"$ & $S+$ & $\mathrm{L}_{-}$ & $"$ & $\begin{array}{c}0.455 \\
(0.108)\end{array}$ & $\begin{array}{c}0.589 \\
(0.002)\end{array}$ \\
\hline " & $S_{-}^{-}$ & $\mathrm{L}+$ & $"$ & $\begin{array}{c}0.517 \\
(0.067)\end{array}$ & $\begin{array}{c}0.575 \\
(0.093)\end{array}$ & $"$ & $S-$ & $\mathrm{L}+$ & $"$ & $\begin{array}{c}0.470 \\
(0.052)\end{array}$ & $\begin{array}{c}0.497 \\
(0.017)\end{array}$ \\
\hline$"$ & $S+$ & Lt & $"$ & $\begin{array}{c}0.473 \\
(0.046)\end{array}$ & 0.521 & $"$ & $S+$ & $\mathrm{Lt}$ & $"$ & $\begin{array}{c}0.477 \\
(0.040)\end{array}$ & $\begin{array}{c}0.498 \\
(0.025)\end{array}$ \\
\hline
\end{tabular}



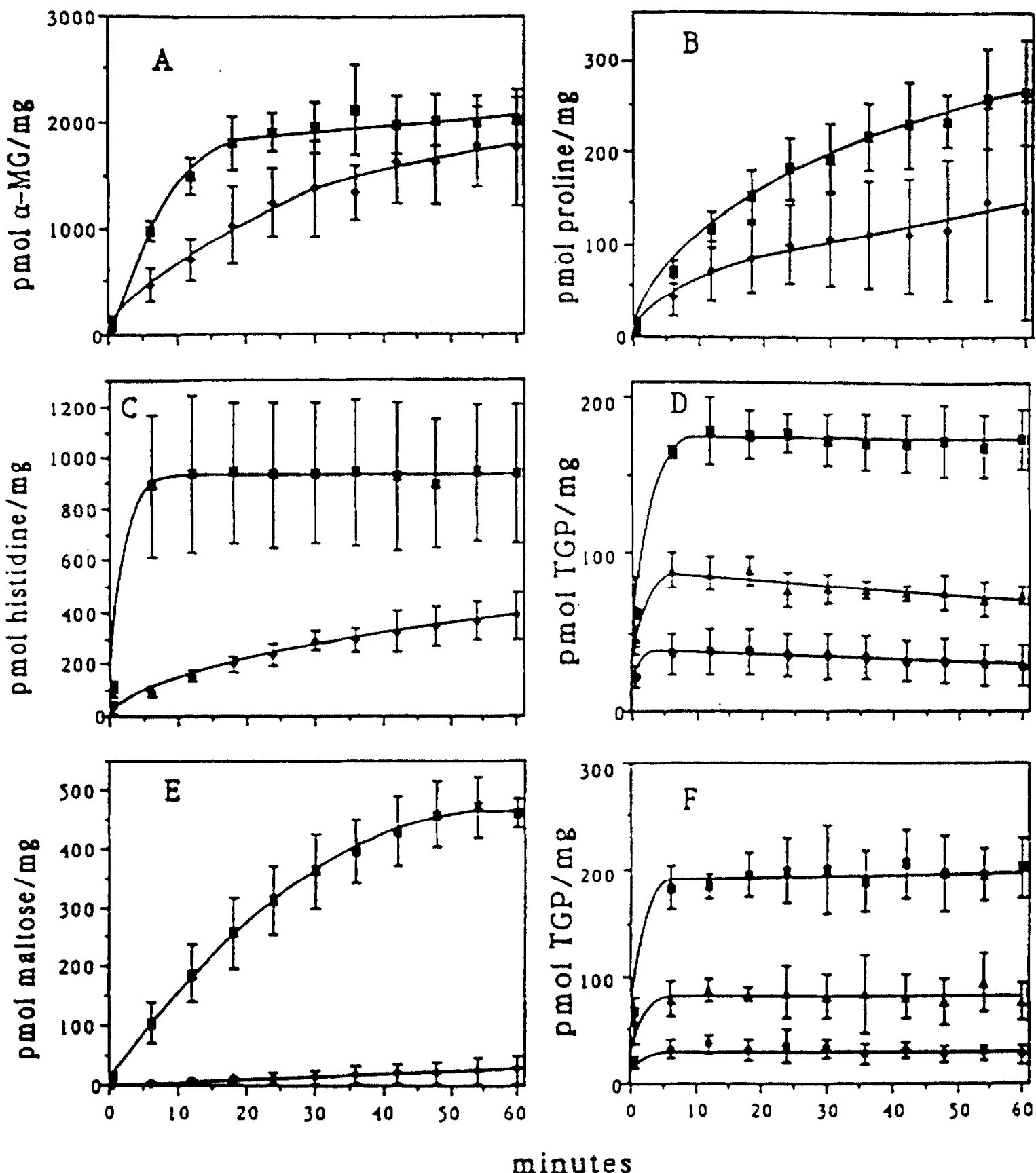

Figure 4. Accumulation over time of labelled molecules by different molecular transport systems for different $E$. coli strains subjected to hyperosmotic stress. A: methyl-( $\alpha-\mathrm{D}-\left[\mathrm{U}-{ }^{14} \mathrm{C}\right]$ glucopyranoside $(\alpha-\mathrm{MG})$, E. coli $\mathrm{MC} 4100 ; \mathbf{B}: \mathrm{L}-\left[\mathrm{U}-{ }_{-}^{14} \mathrm{C}\right]$ proline, E. coli CSGC 5757 ; C: L- $[\mathrm{U}-$ ${ }^{14} \mathrm{C}$ ] histidine, $E$. coli $\mathrm{MC} 4100$; D: [ $\beta$-D-méthyl ${ }^{14} \mathrm{C}$ ] thiogalactopyranoside (TGP), $E$. coli CGSC 6153 (initially grown in the presence of melibiose); E: $\left[\mathrm{U}-{ }^{14} \mathrm{C}\right]$ maltose, $E$. coli CGSC $6153 ; \mathbf{F}:\left[\beta-\mathrm{D}\right.$-methyl $\left.{ }^{14} \mathrm{C}\right]$ thiogalactopyranoside (TGP) E. coli ATCC 25922 (initially grown in the presence of lactose). The cells were washed then suspended in an unsalted buffer (square) (control without hyperosmotic shock), a salted buffer (triangles) or in natural seawater (circle) (hypcrosmotic shock situations). When the effects of seawater were not significantly different from those of the salted buffer, average accumulation was represented by diamonds (curves A, B, C and E). Mean of three experiments \pm SD. From Gauthier et al. [14] 
- light exposure mainly resulted in a drastic decrease in culturable cell numbers, quickly yielding to the detection of only VBNC cells. The energy charge of the cells and their glucose uptake rate were not significantly reduced by the combined effect of light and hyperosmotic stresses, compared with hyperosmotic stress alone.

\subsection{Influence of pre-adaptation on cell survival}

The preceding results refer to exponential-phase bacterial cells, grown in the dark, on a non-salted nutrient-rich medium and immediately suspended in seawater. Under natural circumstances, it is rare that enteric bacteria in their exponential phase are directly released in seawater. Upon leaving the digestive tract, the bacterial cells have probably already reached the stationary phase of growth [14]. Generally, the cells will then be in transit in a waste water discharge network and / or a sewage treatment plant, or even a river, before being discharged into the marine environment. We have observed [9] that Salmonella cells incubated for $24 \mathrm{~h}$ in a sewage treatment plant water develop better survival in seawater than the same cells directly incubated in seawater.

Although it appears to be difficult, if not impossible, to simulate the various pre-adaptation possibilities of enteric bacteria before they are discharged into the sea, we collected some information concerning their survival sensitivity (in terms of culturability loss) as a function of their growth phase, or of pre-incubation in darkness in seawater before exposure to light (figure 5).

Cell sensitivity in response to hyperosmotic stress was highly dependent on the growth phase, being maximal during exponential phase (figure $5 a$ ), and then declining to minimal levels in the stationary phase. The same behaviour was observed, but less clearly, when hyperosmotic stress and exposure to sunlight were combined (figure $5 b$ ).

When log-phase cells were first incubated in the dark in seawater, and then exposed to visible light (figure $5 \mathrm{c}$ ), there was an improvement in their survival, proportional to time spent in pre-incubation conditions.

These results confirm previous studies $[12,13,20,26$, 37], which indicated that the survival of enteric bacteria in the sea is not only dependent on the conditions into which they are released (e.g. direct or indirect discharge, in a turbid or a clear area, during the day or night) in the marine environment, but also on the conditions they were in previously, which could improve their survival.

\subsection{From pre-adaptation phenomena to stress-resistance mechanisms}

The preceding results confirm that bacteria like $E$. coli are able to develop mechanisms to resist adverse conditions. Previous studies on bacterial genetics have shown that cells exposed to different environmental stress conditions (nutrient starvation, hyperosmotic or acid stress) may produce a general anti-stress response, whatever the nature of the stress $[10,18,34]$. In $E$. coli, the general anti-stress response is mediated by the alternate sigma factor $\sigma^{\mathrm{S}}$ which is encoded by the rpoS gene (also known as $k a t F$ ) [31]. The protective effect of rpoS on culturability of stationary-phase E. coli and $S$. typhimurium cells incubated in the dark in oligotrophic seawater was reported by Munro et al. [35].

We also performed different experiments to evaluate the role of this gene with regards to culturability loss in E. coli parental and rpoS mutant strains submitted to separated or combined nutrient deprivation, hyperosmotic shock and light exposure (figure 6).

There was no significant decrease in CFU counts in stationary phase parental and rpoS mutant strains when they were only submitted to nutrient deprivation (figure 6; $\left.\mathrm{OM}_{-}, \mathrm{S}_{-}, \mathrm{L}_{-}\right)$. When exposed to nutrient deprivation and hyperosmotic stress $(\mathrm{OM}-, \mathrm{S}+, \mathrm{L}-)$ or exposure to light (OM-, S-, L+), or all stress (OM-, S+, L+) rpoS mutant strain exhibited a significantly larger decrease than parental strain.

The similar resistance of the strain (rpoS+) and the strain (rpos-) with respect to nutrient deprivation, could be due to a slight sensitivity of the cells to this factor, depending on whether or not they contain the rpos gene, or else that a resistance to lack of nutrients is also dependent on other genes, which are not controlled by rpoS.

The largest difference in CFU decrease between rpoS+ and rpoS- strains exposed to hyperosmotic and light stresses led us to further explore resistance mechanisms of enteric bacteria to these stresses.

\subsection{Resistance to osmotic shock}

It was clear that rpos mutants were sensitive to hyperosmotic shock and that the genes responsible for osmoprotection were at least partly dependent on rpos. Complementary work [14] has also shown that expression of osmoregulated gene proP and proU, coding for the transport of glycine betaine (an osmoprotector), is induced by an increase in osmolarity and undergoes its 


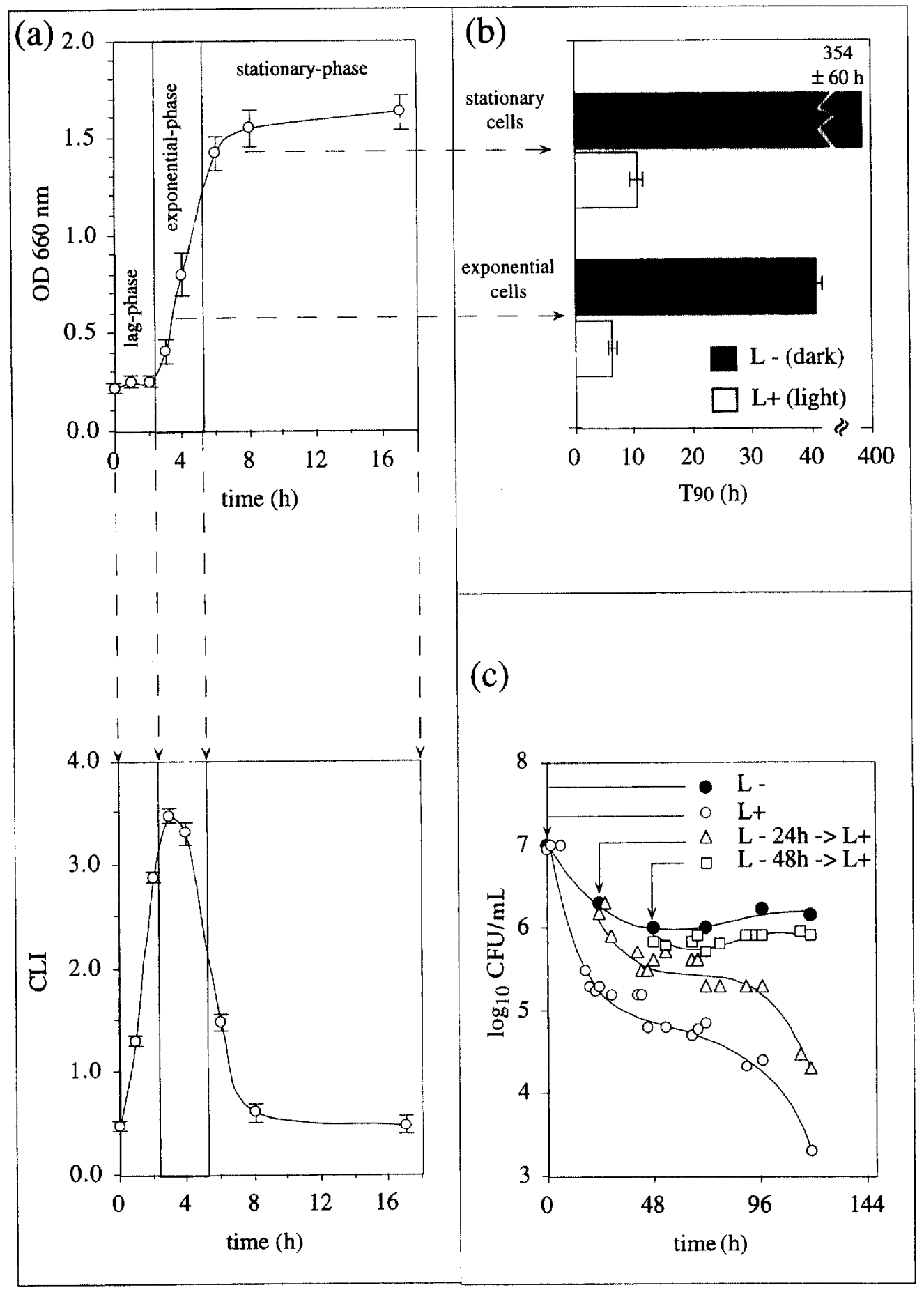

Figure 5. Changes in culturable cellular (CFU) abundance in $E$. coli following pre-adaptation conditions. (a): culturability loss index (log 10 of the ratio of CFU abundance at $\mathrm{T}_{0}$ divided by $\mathrm{CFU}$ abundance after six days incubation in seawater in the dark) as a function of growth phase of the inoculum (mean of three experiments \pm SD); (b): T90 (time (h) required to obtain a $90 \%$ loss of the initial CFU number) estination in seawater with or without light exposure as a function of a growth phase of the inoculum; (c): changes in CFU numbers in seawater exposed to light, following $24 \mathrm{~h}, 48 \mathrm{~h}$ pre-incubation in seawater and darkness, or with no pre-incubation. 


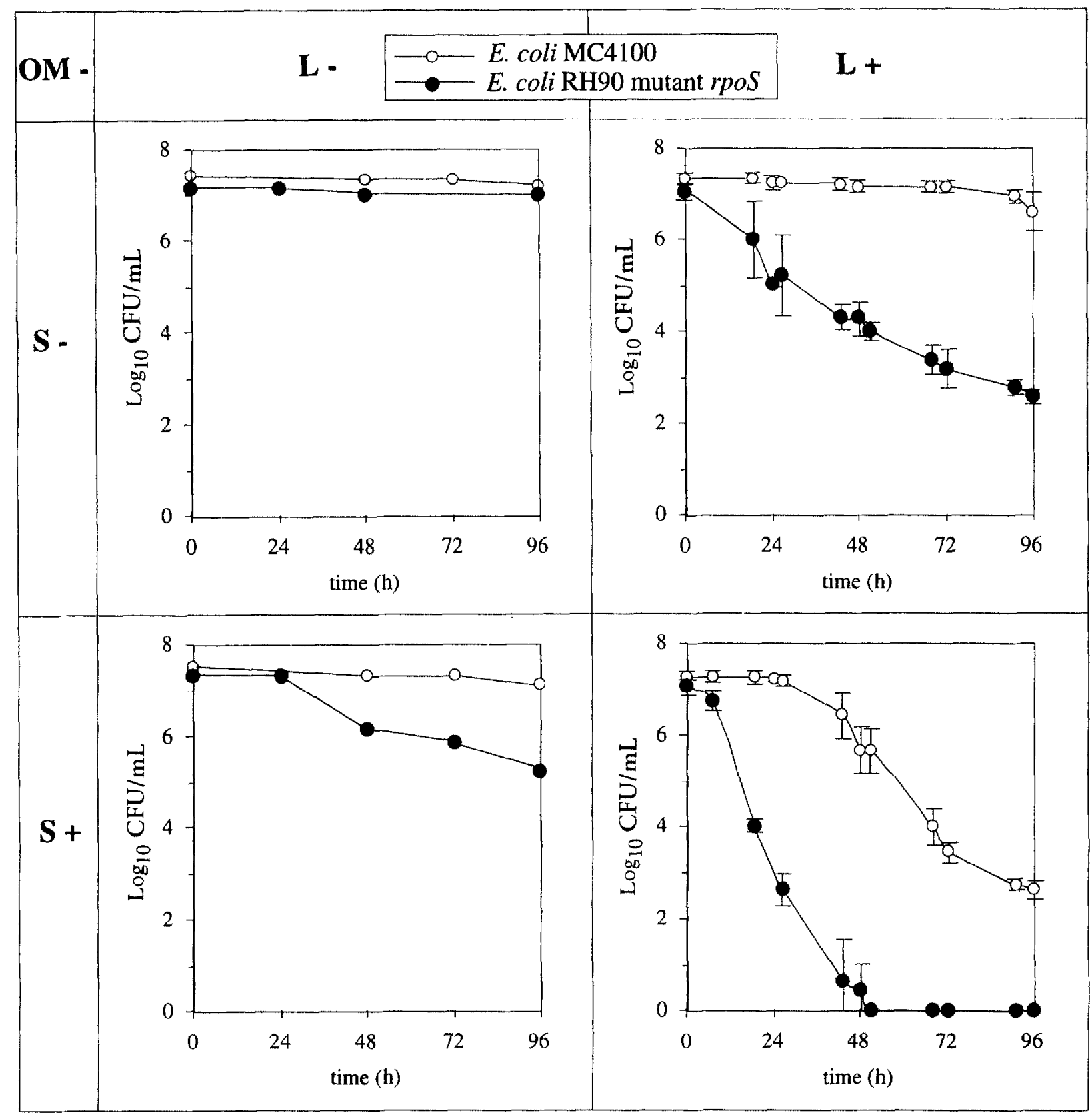

Figure 6. Changes in culturable cellular abundance of stationary phase $E$. coli MC4100 and $E$. coli RH90 mutant rpoS, under the effect of salinity ( $\mathrm{S}-=$ freshwater, $\mathrm{S}+=$ artificial seawater, 34 salinity) and visible light $(\mathrm{L}-=$ incubation in the dark, $\mathrm{L}+=$ continuous exposure to artificial visible light $\left(195 \mathrm{~W} \mathrm{~m}^{-2}\right)$, mean of two experiments $\pm \mathrm{SD}$ ). Experiment undertaken in the absence of nutrients (OM-).

maximum expression when the osmolarity is close to that of seawater. Other experiments [16] have allowed us to observe that accumulation, or synthesis of osmoprotectors (trehalose, glycine betaine, glutamic acid) are only produced if the bacteria have access to nutrients.
While the response of enteric bacteria to osmotic shock is well known in optimal culture conditions $\left(37^{\circ} \mathrm{C}\right.$, nutrient broth) [7], very few studies took into accuunt environmental conditions like those encountered by bacteria after their outfall in coastal waters. Thus, we looked for the 
osmoprotective compounds in Salmonella cells after five days in estuarine waters, at a salinity of 35 , and a temperature of $20{ }^{\circ} \mathrm{C}$. The osmoregulation mechanisms set up varied depending on the available nutrients and compounds (figure 7). Notable differences in the type of accumulated osmoprotector can also appear, depending on the species considered: after incubation in estuarine water
S. manhattan accumulated trehalose, and an unidentified substance (signal at $3.36 \mathrm{ppm}$ in ${ }^{1} \mathrm{H}-\mathrm{NMR}$ ), whereas S. typhimurium accumulated mostly glycine-betaine (figures $7 a$ and $7 d$ ). Trehalose synthesis resulting in an enhanced tolerance to osmotic stress was also observed for $S$. manhattan in oligotrophic seawater following its transit in waste water [9].

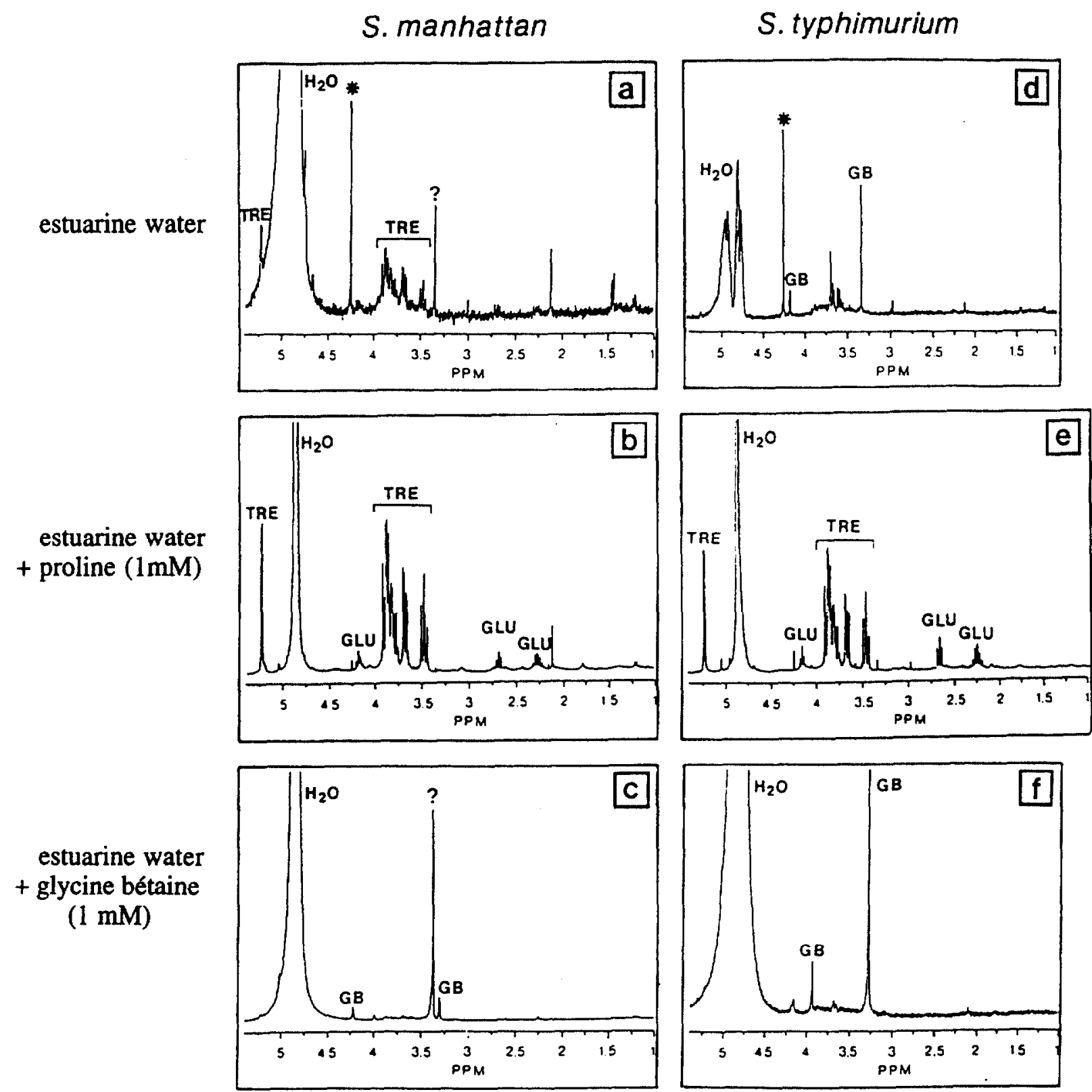

Figure 7. 'H-NMR spectrum of intra-cellular compounds accumulated by two Salmonella serotypes in different environments. a and d, estuarine water; $\mathbf{b}$ and $\mathbf{e}$, estuarine water with $\mathrm{ImM}$ of proline added; $\mathbf{c}$ and $\mathbf{f}$ estuarine water with $1 \mathrm{mM}$ glycine-betaine added. TRE: trehalose; GLU: glutamate; GB: glycine-betaine; *; non-bacterial compounds. 


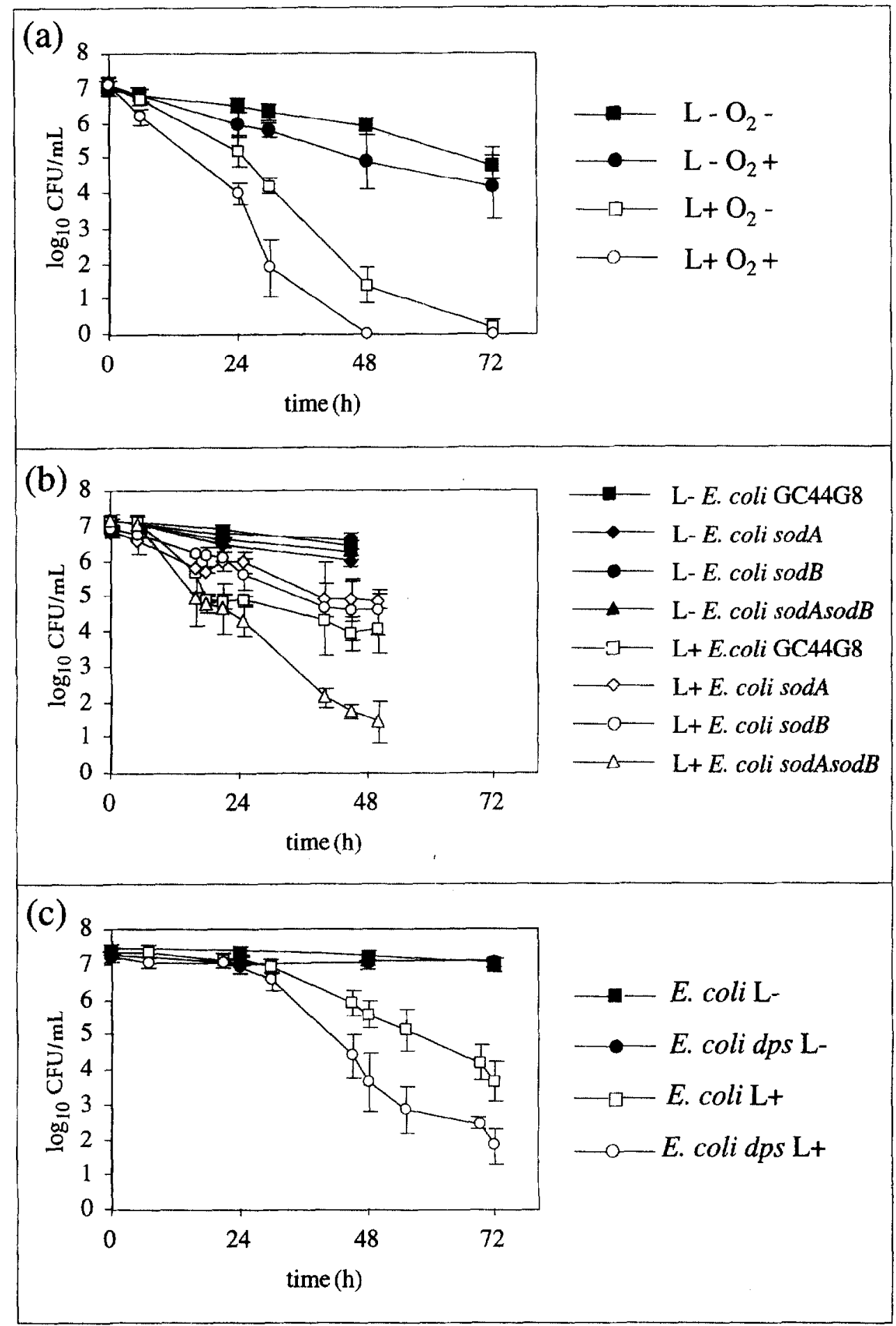

Figure 8. ROS effects on $E$. coli culturable cell ( $\mathrm{CFU}$ ) abundance in seawater. (a): effect of oxygen presence $\left(\mathrm{O}_{2}^{+}\right)$or absence $\left(\mathrm{O}_{2}^{-}\right)$under light exposure $(\mathrm{L}+)$ or absence $(\mathrm{L}-)$; (b): effect of one or two types of superoxyde dismutase deficiency (sodA, $\operatorname{sodB}$, sodAsodB); (c): effect of DNA's protection protein deficiency $(E$. coli $d p s)$. Mean of three experiments \pm SD. 


\subsection{Resistance to the effects of sunlight}

The greatest difference in survival between the rpoS mutant and the parental strain was found when they were exposed to light, which led us to make detailed investigations regarding this factor. We first verified that loss of culturability of the cells was not due to the formation of toxic compounds in seawater. Then, the action of visible light was studied following the hypothesis of production of reactive oxygen species (ROS: reactive oxygen species: singlet oxygen, superoxide anion, hydrogen peroxide and hydroxyl radical) and related cellular response mechanisms.

Firstly, the presence of oxygen in seawater appeared to be a factor which contributed to the loss of culturability in E. coli (figure $8 a$ ). In order to determine the presumed role of ROS, various ROS scavengers were tested, but they did not show a very significant protective effect [17] which leaves us to assume that ROS production in our experiments was poor.

On the other hand, enzymatic activity against the superoxide anion (superoxide dismutase; SOD) or hydrogen peroxide (catalase) did not appear to be significantly modified following light exposure, compared to the control kept in the dark. These enzymes could not be either destroyed or synthesized in oligotrophic seawater (under our experimental conditions). However, the behaviour of sod deficient mutants ( $\operatorname{sod} A$, sod $B$ and $\operatorname{sod} A \operatorname{sod} B$ ) (figure $8 b$ ) and catalase deficient mutants (kat $E$, kat $G$ and $k a t E k a t G$ ) showed that although deficiency in a single type of enzyme did not lead to greater sensitivity to sunlight, the double mutants were more sensitive. Redundancy of defence enzyme production systems could allow the loss of activity of a system to be compensated for hy another.

One cellular target which may be indirectly damaged by visible light through ROS production could be DNA. Various repair and protection systems of bacterial cell genotypes have been described [16]. Using deficient strains in either repair systems ( $\mathrm{rec} A, f p g$ urrA, xth $A$ ) or protection systems ( $d p s$ ), we have been able to show that only $d p s$ deficiency leads to a much stronger loss in culturability than the parental strain (figure $8 c$ ). A hypothesis could be that the tested repair systems are rarely active when exposed to visible light in seawater, but that the cells use a chromosomal DNA protection system by producing a histone-like protein coded by $d p s$ and controlled by rpoS, which forms highly complex structures with DNA [1].

\subsection{Consequences of general anti-stress response}

One consequence of regulation of stress responses by $r p o S$, is that their induction by a particular "marine" stress factor could adapt the cells to other stresses than those encountered in the marine environment. Thus, let us suppose that an enteric bacterium which had been released into the sea was ingested by a person through contaminated seafood. This bacterium would have to overcome the gastric barrier to develop its pathogenic ability (if it had been conserved) in the intestine. It must therefore be able to resist low gastric $\mathrm{pH}(\mathrm{pH} 2.5,2 \mathrm{~h})$. Consequently, we examined whether acid resistance could be modified after incubation in seawater. The results obtained [11] indicated that acid resistance of different enteric bacteria was greatly enhanced after $100 \mathrm{~min}$ in seawater (figure 9).

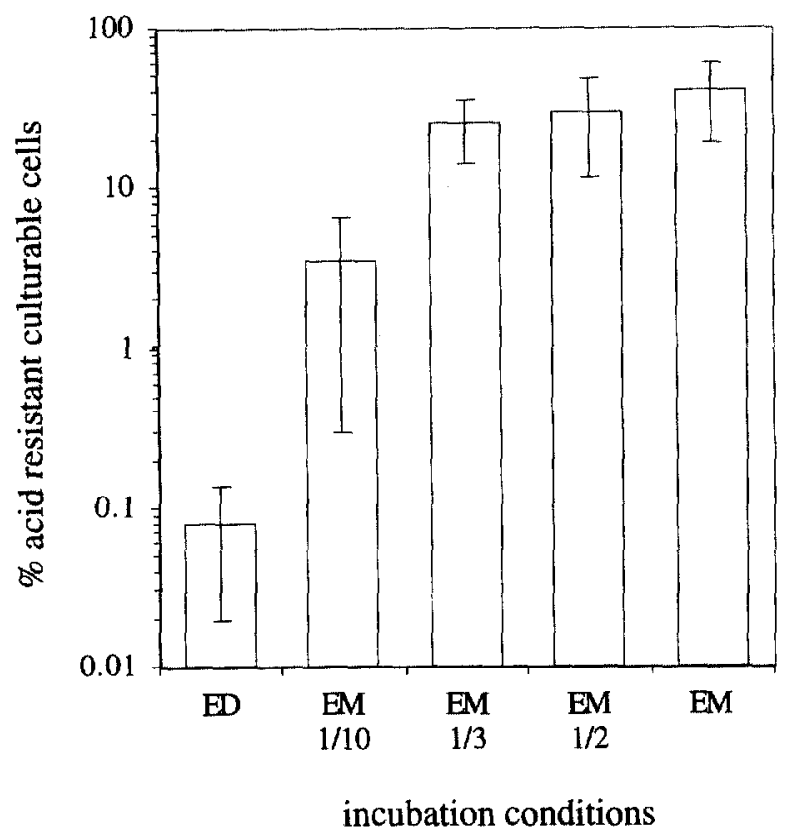

Figure 9. Acid resistance ( $\mathrm{pH} 2.5$ for 2 h) of $E$. coli $\mathrm{MC4} 100$ cells, following $100 \mathrm{~min}$ incubation in distilled water (ED) or in seawater (EM) diluted or non-diluted. Mean of three experiments \pm SD.

Thus, acquired resistance to marine environmental stresses may have indirect sanitary implications. However, such implications only concern the cells which have maintained their viability. The latter point leads us to present some results on cellular state changes to complete the preceding results which mainly refer to culturable cells. 


\subsection{Cellular state dynamics during survival}

Loss of culturability is only one evolutionary stage that bacterial cells undergo when subjected to a hostile environment. Detection of VBNC cells shows us that cells of the same population do not have the same behaviour when confronted with the marine environment. So, to establish and test the concepts and processes governing the fate of enteric hacteria in the marine environment, it is important to define the different sub-populations which could appear, and to describe their dynamics.

We have studied the succession of physiological states of $S$. typhimurium cells under starvation-survival conditions in seawater by flow cytometry and epifluorescence microscopy using direct examination of different cellular functions: substrate responsiveness (DVC method), respiratory activity in the presence or absence of substrate (CTC redox dye), membrane permeability (BacLight ${ }^{\mathrm{TM}}$ kit), as well as DNA content (Hoechst 33342 staining).

Analysis of changes in the abundance levels of sub-populations defined using these cellular characteristics [22] has enabled us to propose a definition and possible succession of different states or cellular categories, from a culturable state up to lysis, as well as their relative evolution over time (figure 10).

It must be said that although the pattern suggesting a progressive physiological cellular degradation agrees with our knowledge of cell physiology (successive loss of multiplication activity, synthesis activity, respiratory activity, and then of membrane permeability and genome content), we do not know if all cells follow this path in each of their stages, nor if they will reach one or another of these stages in a simultaneous fashion.

Our results confirm that not all the cells from the same initial population will have the same fate, even if they are subjected to the same environmental conditions. For example, certain cells conserve their ability to grow or respire, whilst at the same time others will no longer show these characteristics. The information gathered also shows the existence of at least two cellular categories, other than culturable cells and VBNC cells: nonculturable cells, which are not active, but show membrane and genome integrity (dormant cells), and nonculturable inactive cells, which have lost genome and membrane integrity. The latter are certainly in a state close to cellular death which is of course irreversible. These results imply that survival theories and associated mathematical models have to take into account the existence of differ- (a)
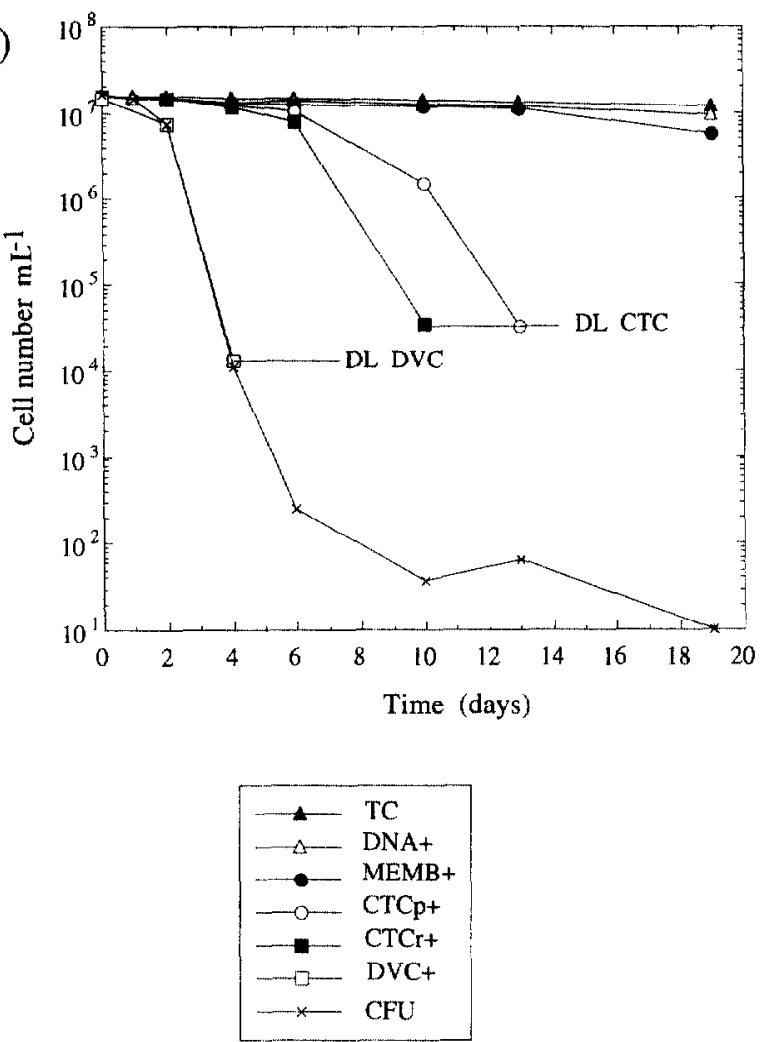

(b)

\begin{tabular}{|l|c|c|c|c|c|c|c|}
\hline & \multicolumn{5}{|c|}{ cellular states } \\
\hline cellular characteristics & $\mathrm{C}$ & $\mathrm{VBNC}_{\mathrm{I}}$ & $\mathrm{VBNC}_{\mathrm{II}}$ & $\mathrm{VBNC}_{\mathrm{III}}$ & $\mathrm{VBNC}_{\mathrm{IV}}$ & $\mathrm{NVNC}$ & $\mathrm{M}$ \\
\hline culturable (CFU) & + & - & - & - & - & - & - \\
\hline real respiration (CTCr) & + & + & - & - & - & - & - \\
\hline potential respiration (CTCr) & + & + & + & - & - & - & - \\
\hline membrane permeability (MEMB) & + & + & + & + & - & - & - \\
\hline genomic integrity (DNA) & + & + & + & + & + & - & - \\
\hline cellular integrity (TCI & + & + & + & + & + & + & - \\
\hline
\end{tabular}

Figure 10. (a) Changes in Salmonella typhimurium cells showing different cellular characteristics during incubation in seawater in the dark. TC: Total count; DNAt: cells whose content is equal or superior to one equivalent genome; MEMB+: cells which have unmodified membrane permeability; CTCp+: cells showing respiratory activity after nutrient addition; $\mathrm{CTCr}+$ : cells showing respiratory activity with no nutrient addition; DVC + : cells showing metabolic activity in the presence of nutrients; $\mathrm{CFU}+$ : cells showing a capacity to form colonics on a culture medium. (b) definition of different cellular categories as a function of characteristics shown by the cells. C: culturable cells: VBNC I: viable but nonculturable cells type I; VBNC II: viable but nonculturable cells type II; VBNC III: VBNC cells type III; VNC IV: VBNC cells type IV; NVNC: non-viable nonculturable cells; $M$ : lysed cells. 
ent cellular categories, and their specific evolutionary processes.

\section{CONCLUSION AND PERSPECTIVES}

Before the 1980s, the concept of seawater self-purification and of quick bacterial death prevailed. Over the past fifteen years our perception of the fate of enteric bacteria in the marine environment has been greatly modified.

The existence of a dormant state, or a VBNC state, reported for a large number of bacterial species in aquatic environments [36], has had, and will continue to have, numerous fundamental and applied consequences.

It has firstly enabled us to reconsider more precisely the effects of environmental factors specific to the marine ecosystem. With regard to the results obtained, the different experimentally reproduced stresses do not seem to affect the global physiological characteristics of the cell in the same way. Nutrient deprivation alone induced the most limited functional changes, at least in the short term, but when combined with hyperosmotic shock, it notably results in depletion of energy reserves and inactivation of membrane transport. Sunlight mainly affects, directly or indirectly, the capacity for cellular division, as it appears that light exposure leads to a very strong inhibition of cells' ability to form colonies. However, culturability loss is not an unambiguous criterion of the cell division inability. Other physiological modifications could lead, more or less quickly, to a loss in culturability $[15,43]$.

It has also been shown that survival of $E$. coli cells is not solely dependent on the environmental conditions to which they are exposed in seawater. In an apparently paradoxical way, if an $E$. coli population is submitted to an initial stress, resistance to a second successive stress will be improved. If, for example, nutrient starvation is imposed before osmotic shock, the number of surviving cells is higher than when the cells are incubated directly in seawater; but this paradox is only apparent. The explanation is provided by analysis of stress resistance mechanisms which were carried out using recent information on bacterial genetics, focusing on the central role of the gene $r p o s$. This gene was shown to trigger a general anti-stress response (accumulation or synthesis of osmoprotectors, production of stress proteins...) which may be induced by different stresses. Once triggered by a primary stress, this response allows improved survival of subsequent stress. However, numerous aspects concerning adaptation and pre-adaptation phenomena need to be explored: duration of their efficiency, regulation factors, or the stochastic or deterministic nature of their expression $[41,46]$. Besides obtaining a better understanding of the fate of enteric bacteria in seawater, better knowledge of pre-adaptation phenomena could constitute a new basis for reflection about waste water treatments. For instance, could we consider that certain treatment procedures enhance these phenomena? Could we limit the extent of these phenomena or should we develop more drastic treatments, which would lead to a permanent inability to divide?

Numerous questions remain, or will arise concerning the work which we have presented. At least two of these deserve mention, as they could lead to new research directions.

Firstly, we do not know the relationship, if any, hetween VBNC states and stress-resistance mechanisms $[23,36]$. Until now the latter was principally analysed through comparison of the fates of mutant and parental strains using culture techniques. If we therefore consider that the described processes only concern culturability preservation, the VBNC state may not be related to these processes. Further research must include the comparison of VBNC cell generation and dynamics in mutant and parental strains.

On the other hand, the terminology for the VBNC state remains a source of debate [4]. It should always be made with reference to the method used which, as we have previously indicated, is actually based on the presence of cellular activity in cells which have lost their ability to be cultured. It is in this sense that we have employed the term VBNC, i.e. restrictively speaking. This does not allow any definitive conclusion to be made on the ability to multiply, as standard conditions (culture medium) might not meet the requirements of cells in a particular physiological state. The results obtained by flow cytometry, and use of different fluorescent markers, are a good illustration of "hidden" diversity in cellular states under the term VBNC. This cellular diversity, and its change over time, should be studied in more depth, by making use of cellular sorting techniques to estimate the ability of different sub-populations to recover certain lost functions [24]. Finally, the demonstration of the existence of different cellular physiological states in enteric bacteria, during their survival in marine water, brings to light the question of whether there is a relationship between the loss of pathogenic characteristics and the progressive physiological cell alteration. 
To conclude, even if numerous questions remain, our current knowledge of enteric bacteria responses to environmental marine stresses allows, and even requires, that we resort to deterministic models taking into account cellular state heterogeneity. This step will show its utility by formalising the still numerous gaps in our knowledge.

\section{Acknowledgment}

This work was supported by funds provided by the Programme national d'océanographie côtière, "Microbiologie sanitaire" sub-program.

\section{REFERENCES}

[1] Almiron M., Link A., Furlong D., Kolter R., A novel DNA binding protein with regulatory and protective roles in starved Escherichia coli, Genes Dev. 6 (1992) 2646-2654.

[2] Atkinson D.E., The energy charge of the adenylate pool as a regulatory parameter, Interaction with feedback modifiers, Biochem. 7 (1968) 4030-4034.

[3] Barcina I., Gonzalez J.M., Iriberri J., Egea L., Effect of visible light on progressive dormancy of Escherichia coli cells during the survival process in natural freshwater, Appl. Environ. Microbiol. 55 (1989) 246-251.

[4] Barer M.R., Gribbon L.T., Harwood C.R., Nwoguh C.E., The viable but non-culturable hypothesis and medical bacterinlogy, Rev. Med. Microbiol. 4 (1993) 183-191.

[5] Brayton P.R., Roszak D.B., Palmer L.M., Huq S.A., Grimes D.J., Colwell R.R., Fluorescent antibody enumeration of Vibrio cholerae in the marine environment, in: Gerbam (Ed.), Deuxième Colloque International de Bactériologie Marine, IFREMER, Actes de Colloques 3, Brest, 1986, 507-514.

[6] Casabadan M.J.. Transposition and fusion of the lac genes to selected promotors in Escherichia coli using bacteriophage lambda and Mu, J. Mol. Biol. 104 (1976) 541-555.

[7] Csonka L.N., Physiological and genetic responses of bacteria to osmotic stress, Microbiol. Rev. 53 (1989) 121-147.

[8] Curtis T.P., Mara D., Silva S.A., Influence of pH, oxygen, and humic substances on ability of suniight to damage fecal coliforms in waste stabilization pond water, Appl. Environ. Microbiol. 58 (1992) 1335-1343.

[9] Dupray E., Derrien A., Pichon R., Osmoregulation by trehalose synthesis in Salmonella manhattan after exposure to waste waters, Lett. Appl. Microbiol. 20 (1995) 148-151.

[10] Eisenstark A., Calcutt M., Becker-Hapak M., Ivanova A., Role of E.coli rpoS and associated genes in defense against oxidative damage, Free Rad. Biol. Med. 21 (1996) 975-993.

[11] Gauthier M.J., Clément R.L., Effect of a short period of starvation in oligotrophic waters on the resistance of enteric bacterial pathogens to gastric $\mathrm{pH}$ conditions, FEMS Microbiol. Ecol. 14 (1994) 275-284.

[12] Gauthier M.J., Munro P.M., Breittmayer V.A., Influence of prior growth conditions on low nutrient response of Escherichia coli in seawater, Can. J. Microbiol. 35 (1989) 379-383.
[13] Gauthier M.J., Flatau G.N., Clément R.L., Munro P.M., Sensitivity of Escherichia coli cells to seawater closely depends on their growth stage, J. Appl. Bact., 73 (1992) 257-262.

[14] Gauthier M.J., Munro P.M., Flatau G.N., Clément R.L., Breittmayer V.A., Nouvelles perspectives sur l'adaptation des entérobactéries dans le milieu marin, Mar. Life 3 (1993) 1-18

[15] Genthner FJ., Upadhyay J., Campbell R.P., Sharak Genthner B.R., Anomalies in the enumeration of starved bacteria on culture media containing nalidixic acid and tetracycline, Microbiol. Ecol. 20 (1990) 283-288.

[16] Gourmelon M., Étude de la lumière visible comme facteur limitant de la survie de Escherichia coli en milieu marin. Thèse Doct. Univ. Rennes I (1995) 144 p.

[17] Gourmelon M., Cillard J., Pommepuy M., Visible light damage to Escherichia coli in seawater: oxidative stress hypothesis, J. Appl. Bact. 77 (1994) 105-112.

[18] Hengge-Aronis R., Back to log phase: $\sigma^{*}$ as a global regulator in the osmotic control of gene expression in Escherichia coli, Mol. Microbiol. 21 (1996) 887-893.

[19] Holm-Hanssen O., Booth C.R., The measurement of adenosine triphosphate in the ocean and its ecological significance, Limnol. Oceanogr. 11 (1966) 510-519.

[20] Jenkins D.E., Schultz J.E., Matin A., Starvation induced crossprotection against heat or $\mathrm{H}_{2} \mathrm{O}_{2}$ challenge in Escherichia coli, J. Bacteriol. 170 (1988) 3910-3914.

[21] Jepras R.I, Carter J., Pearson S.C., Paul F.E., Wilkinson M.J., Development of a robust flow cytometric assay for determining numbers of viable bacteria, Appl. Environ. Microbiol. 61 (1995) 2696-2701.

[22] Joux F., Lebaron P., Troussellier M., Succession of cellular states in a Salmonella typhimurium population submitted to starvation in artificial seawater microcosms, FEMS Microbiol. Ecol. 22 (1997) 65-76.

[23] Kaprelyants A.S., Gottschal J.C., Kell D.B., Dormancy in nonsporulating bacteria, FEMS Microbiol. Rev. 104 (1.993) $271-$ 286.

124] Kaprelyants A.S., Mukamolova G.V., Davey H.M., Kell D.B., Quantitative analysis of the physiological heterogeneity within starved cultures of Micrococcus luteus by flow cytometry and cell sorting. Appl. Environ. Microbiol. 62 (1996) 1311-1316.

[25] Kjelleberg S., Starvation in bacteria, Plenum Press, New York, $1993,277 \mathrm{p}$. 
[26] Kjelleberg S., Hermanson M., Mardén P., The transient phase between growth and nongrowth of heterotrophic bacteria with emphasis of the marine environment, A. Rev. Microbiol. 41 (1987) 25-49.

[27] Kogure K., Simidu U., Taga N., A tentative direct microscopic method for counting living marine bacteria, Can. J. Microbiol. 25 ( 1979) 415-420.

[28] Laborde P., L'adénosine triphosphate des microorganismes marins planctoniques, Rapport avec la biomasse et la productivité primaire. Thèse Doct. Océanogr. Univ. Aix-Marseille II (1972) $108 \mathrm{p}$.

[29] L ehaton P., Jonx F., Flow cytometric analysis of the cellular DNA content of Salmonella typhimurium and Alteromonas haloplanktis during starvation and recovery in seawater, Appl. Environ. Microbiol. 60 (1994) 4345-4350.

[30] Lebaron P., Roux V., Lett M.C., Baleux B., Effects of pili rigidity and energy availability on the conjugative transfer of plasmids in aquatic environments, Microbiol. Releases 2 (1993) $127-133$.

[31] Loewen P.C., Hengge-Aronis R., The role of the sigma factor $\sigma^{s}$ (KatF) in bacterial global regulation. Ann. Rev. Microbiol. 48 (1994) 53-80.

[32] López-Amorós R., Comas J., Vives-Rego J., Flow cytometric assessment of Escherichia coli and Salmonella typhimurium starvation-survival in seawater using rhodamine 123, propidium iodide, and oxonol, Appl. Environ. Microbiol. 61 (1995) 2521-2526.

[33] Maniatis T., Fritsch E.F., Sambrook J., Molecular cloning. a laboratory manual, Cold Spring Harbor Laboratory, Cold Spring Harbor, N.Y. (1982).

[34] Munro P.M., Clément R.L., Flatau G.N., Gauthier M.J., Effect of thermal, oxidative, acidic, osmotic or nutritional stresses on subsequent culturability of E.coli in seawater, Microbiol. Ecol. 27 (1994) 57-63.

[35] Munro P.M., Flatau G.N., Clément R.L., Gauthier M.J., Influence of the RpoS (KatF) sigma factor on maintenance of viahility and culturability of Escherichia coli and Salmonella typhimurium in seawater, Appl. Environ. Microbiol. 61 (1995) 1853-1858.

[36] Oliver J.D., Formation of viable but nonculturable cells, in: Kjelleberg S. (Ed.J, Starvation in bacteria, Plenum Press. New York, 1993, 239-272.
[37] Pommepuy M., Guillaud J.F., Dupray E., Derrien A., Le Guyader F. Cormier M., Enteric bacterial survival factors, Wat. Sci. Tech. 25 (1992) 93-103.

[38] Porter J., Diaper J., Edwards C., Pickup R., Direct measurements of natural planktonic bacterial viability by flow cytometry. Appl. Environ. Microbiol. 61 (1995) 2783-2786.

[39] Pyle B.H., Broadaway S.C., McFeters G.A., A rapid direct method for enumerating respiring enterohemorragic Escherichia coli $\mathrm{O} 157: \mathrm{H} 7$ in water, Appl. Environ. Microbiol. 61 (1995) 2614-2619.

[40] Rahman I.. Shahamat M.. Kirchman P.A., Russek-Cohen E., Colwell R.R., Methionine uptake and cytopathogenicity of viable but nonculturable Shigella dysenteriae type 1. Appl. Environ. Microbiol. 60 (1994) 3573-3578.

[41] Rainey P.B., Moxon E.R., Thompson I.P., Intraclonal poplymorphism in bacteria, in: Jones G. (Ed.), Advances in Microbial Ecology, Plenum Press. New York, Vol. 13, 1993, 263300 .

[42] Rodriguez G.G., Phipps D., Ishiguro K., Ridgway H.F., Use of a fluorescent redox probe for direct visualization of actively respiring bacteria, Appl. Environ. Microbiol. 58 (1992) 18011808.

[43] Roth W.G., Leckie M.P., Dietzler D.N., Restoration of colonyforming activity in osmotically stressed Escherichia coli by betaine, Appl. Environ. Microbiol. 54 (1988) 3142-3146.

[44] Troussellier M., Courties C., Vaquer A., Recent applications of flow cytometry in aquatic microbial ecology, Biol. Cell, 78 (1993) 111-121.

[45] Wright R.T., Hobbie J.E., Use of glucose and acetate by bacteria and algae in aquatic ecosystems, Ecology, 47 (1966) 447464.

[46] Zambrano M.M., Kolter R., Starvation and death of Escherichia coli in stationary phase, in: Guerrero R., Pedros-Alio C. (Eds.), Trends in Microbial Ecology, Spanish Society for Microbiology, Barcelona, 1993, 179-182.

[47] Zimmerman R., Itturiaga R., Becker-Birck J., Simultaneous determination of the total number of aquatic bacteria and the number thereof involved in respiration, Appl. Environ. Microbiol. 36 (1978) 926-935. 